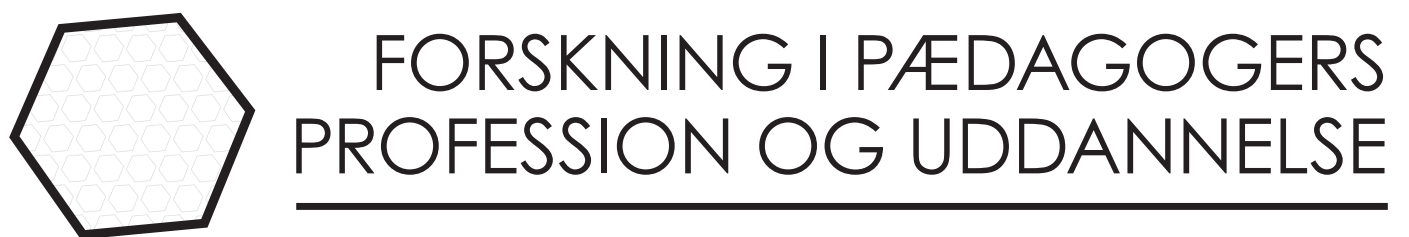

\title{
Ungeperspektiver på trivsel i udskolingen
}

- som afscet for paedagogens trivselsarbejde

\section{Lea Ringskov \\ lektorVIA UC, lri@via.dk}

\section{David Thore Gravesen}

\author{
lektor og phd, VIA UC, dtg@via.dk
}




\title{
Resume
}

Forskning dokumenterer at unges trivsel daler i udskolingen. I artiklen præsenterer vi analyser fra aktionsforskningsprojektet "Podagogen som trivselsaktør $i$ udskolingen", der undersøger unges perspektiver på trivsel i udskolingen og pædagogens rolle i denne forbindelse. I første fase af projektet, som denne artikel tager udgangspunkt i, undersøgte vi de unges egne perspektiver på trivsel i skolen. Ved hjælp af et multimodalt undersøgelsesdesign indsamlede vi empiri med udgangspunkt i de unges perspektiver. Empirien danner baggrund for en abduktiv analyse, der præsenterer fire kategorier, hhv. fællesskaber, frikvarter, fag og frihed. De fire empiriske kategorier udforskes ved hjælp af Helle Rabøl Hansens forståelse af skoletrivsel, forankret i begreberne velvære, virke og vellidthed. Konklusionen er, at kategorien fællesskab, der i høj grad konnoterer vellidthed, men ligeså er forbundet med velvære og virke, fremstår som den dominerende markør i de unges forståelse af trivsel i skolen. I afrundingen samler vi ved hjælp af andre forskningsresultater om trivsel op på pointen om fællesskab som central markør i forhold til den videre refleksion over pædagogen som trivselsaktør i udskolingen.

\begin{abstract}
In this article, we present analytical perspectives from the first phase of a participatory action research project entitled "The pedagogue as well-being agent in the secondary school". With pedagogues and young people as co-researchers we have collected empirical data concerning the young people's own perspectives on their well-being as a point of departure for the pedagogue working as a well-being agent. In the analysis, four empirical categories are constructed: Communities, recess, subjects and freedom, with the first marking the dominating category. When closing the article, we invite readers to reflect on the role of the pedagogues on the basis of the young people's perspectives on well-being.
\end{abstract}

\section{Nøgleord}

Trivsel, ungeperspektiver, aktionsforskning, udskoling, pædagoger

\section{Keywords}

Well-being, youth perspectives, participatory action research, secondary school, pedagogues 


\section{Indledning}

Forskning dokumenterer, at trivslen hos børn og unge daler i udskolingsårene (Görlich, Pless, Katznelson, \& Graversen, 2019). I en undersøgelse fra VIVE indkredses en dalende skoletrivsel gennem påvisning af stigning i skoleskift på grund af mistrivsel, et øget antal konflikter og et fald i antal elever, der kan lide skolen og føler, de klarer sig godt fagligt. Den psykiske trivsel daler fra 11 år og op (Ottesen, et al., s. 193-196). Flere undersøgelser kaster lys over centrale omdrejningspunkter i udskolingen, der på forskellig vis har betydning for unges trivsel (Pless, Katznelson, Hjort-Madsen \& Nielsen, 2015; Rasmussen, 2017; Pless \& Sørensen (red.), 2018; Brown, Falkenberg og Rasmussen, 2020), ligesom en række publikationer, såvel danske som internationale (Knoop, Holstein, Viskum \& Lindskov, 2017; Powell et al., 2015; Simmons, Graham \& Thomas, 2015; Nielsen 2020), retter fokus direkte mod unges egne perspektiver på trivsel i skole og ungdomsuddannelse. Her konkluderes samstemmende, at fællesskaber og relationer til andre elever og lærere er centrale forudsætninger for trivsel.

I pædagogisk litteratur fremhæves pædagogen ofte som trivselsaktør med særlige trivselskompetencer. F.eks. indkredses trivsel som ét ud af fire pædagogfaglige kerneområder af Ankerstjerne og Stæhr (2018, s. 13) (Kofoed-Heller, Hansen, \& Dupont, 2017; Højholdt, Arndal, Blaabjerg \& Højmark, 2015), ligesom evalueringer af SFO og klub fremhæver, at et kendetegn ved kvalitet i fritidstilbud er personalets systematiske vidensindsamling og -deling omkring trivsel (EVA, 2016, s. 9-10). Imidlertid benytter kun hver sjette skole sig af pædagoger i udskolingen og pædagogens rolle som trivselsaktør, ikke mindst i udskolingen, er underbelyst (Epinion, 2017, s. 50).

I vores aktionsforskningsprojekt er målet:

- At skabe viden om de unges perspektiver på trivsel (fase 1)

- At skabe viden om eksisterende pædagogiske trivselsindsatser (fase 2)

- På baggrund af viden fra fase 1 og 2 at afprøve nye trivselsindsatser (Fase 3)

I nærværende artikel retter vi fokus på den del af projektet, der genererer viden om de unges perspektiver på egen trivsel (fase 1), med følgende forskningsspørgsmål: "Hvad er unges egne perspektiver på trivsel $i$ skolen, og hvordan kan denne viden danne baggrund for refleksioner omkring padagogens rolle som trivselsaktør i udskolingen?".

Baggrunden for projektets fokus på trivsel og trivselsbegrebet betragter vi todelt;

1. Som vi vil anskueliggøre i det næste afsnit, er der en stigende samfundsmæssig, strukturel, pædagogisk og voksenbaseret interesse for trivsel, og hvordan trivsel kan forstås i relation til formel læring i skolesammenhænge (Marschall \& Thingstrup, 2019; Thingstrup, 2019). Sådanne spørgsmål håndteres ofte kvantitativt i form af surveys, nationale trivselsmålinger etcetera. Som undervisere og forskere deler vi denne interesse. 
2. Hertil vurderer vi, at den kvalitative metodik i dette studie kan være et relevant og vigtigt bidrag eller supplement til den viden vi allerede har, særligt fordi indeværende studie fokuserer på de unges perspektiver, oplevelser og erfaringer. Her er det således ikke ønsket om at forstå trivsel som forudsætning for læring, der har forrang, men nærmere de unges egne forståelser af trivsel i skolen. Med netop dette afsæt, ønsker vi at artiklen her kan fungere som inspiration for videre refleksioner over pædagogens rolle i udskolingen. ${ }^{1}$

\section{Metode og teori}

De sidste 15 år har interessen for trivsel været stigende, både politisk, pædagogisk og i forskning (Marschall \& Tingstrup, 2019). Trivsel fremstår som et komplekst og mangfoldigt begreb, der indholdsudfyldes forskelligt, alt afhængig af afsenderens interesser, position, kultur og tid (Marschall \& Tingstrup, 2019; Lind 2019; Ereaut \& Whiting, 2008). Ifølge Ereaut og Whitnings er trivsel et ustabilt begreb - en slags "filler, extender or catch-all" kategori (Ereaut \& Whiting, 2008, s. 7). Kompleksiteten og de mange forskellige interessenter, perspektiver og positioneringer synes at sløre begrebets betydning (Crivello, Camfield, \& Woodhead, 2008).

At forske i trivsel medfører en række spørgsmål: skal trivsel undersøges og betragtes som et individuelt eller kollektivt fænomen, eller både og? Er trivsel at betragte som en objektiv eller subjektiv størrelse, eller både og? Er trivsel noget der er, som kan defineres, afgrænses og måles eller er det et socialt konstrueret, dynamisk, kontekstuelt og foranderligt fænomen, der umuliggør en entydig definition? (Marschall \& Tingstrup, 2019; Lind, 2019; Hansen, 2019; Crivello, Camfield $\&$ Woodhead, 2008).

I indeværende forskningsprojekt søger vi ikke at fremkomme med en entydig definition på trivsel. Nærmere placerer vi os i forlængelse af de videnskabelige positioner, der fastholder kompleksitet, foranderlighed og social konstruktion som epistemologisk præmis.

Forskningsprojektet er designet som et aktionsforskningsprojekt (Brydon-Miller et al. 2003, Duus, 2015), der forløber fra 2020 til 2021. Centralt i aktionsforskning er en fundamental "respect for people and for the knowledge and experience they bring to the research process, a belief in the ability of democratic processes to achieve positive social change and commitment to action" (Brydon-Miller et al. 2003, p. 15). I projektet deltager unge fra fire udskolingsklasser fra fire skoler i to jyske kommuner. Fra hver skole deltager to pædagoger, dvs. i alt otte pædagoger ${ }^{2}$.

1 Denne artikel tager som beskrevet udgangspunkt i fase 1, hvor vi har indsamlet data om de unges egne perspektiver på trivsel. Når de næste faser af projektet er gennemført, vil vi publicere materiale, der direkte omhandler disse faser. Hertil vil vi også i forbindelse med projektets afslutning, publicere en artikel, der kondenserer fund fra samtlige faser og giver et samlet blik på erkendelser i projektet. Projektets endelige analyser af pædagogens rolle vil læsere således kunne studere i de kommende publikationer.

$2 \quad$ For at sikre anonymitet er alle navne på deltagende informanter og skoler ændret. 
Gennem projektets tre faser deltager både unge og pædagoger som medforskere, hvor de producerer empiri, deltager i analytiske workshops og afprøver konkrete aktioner omkring trivsel i udskolingen. Viden konstrueres i projektet gennem samarbejdet og i mødet med de unge og pædagogerne. Endvidere følger vi aktionsforskningens ambition om at skabe positiv forandring i praksis blandt andet gennem styrkelse af pædagogernes faglighed (Duus et al. 2014; Jensen 2017). Nærmere bestemt betragter vi især fase 3 som en afprøvnings- og udviklingsfase, hvad angår pædagogernes faglighed omkring trivselsindsatser i udskolingen. På baggrund af de unges perspektiver og den viden, deltagerne sammen med os som forskere producerer i fase 1 og 2 , afprøver pædagogerne således i fase tre nye trivselstiltag og gennem disse er tager pædagogerne således livtag med refleksion over og udvikling af deres faglighed.

Ungeperspektivet står centralt i projektet. Dermed følger vi en generel tendens inden for nyere børne- og ungeforskning, hvor fokus rettes mod børns og unges perspektiver og egne forståelser af det hverdagsliv, som de betragtes som eksperter i (Gravesen, et al. 2019; Clark \& Statham, 2005; James, 2007). For at invitere de unge ind som medforskere, opererer vi med et multimodalt undersøgelsesdesign, der involverer indsamling af visuelle og kreative materialer (fotos, tegninger og digte) fra de unge, samt observationer og fokusgruppeinterviews. Metoderne retter sig mod de unges egne udtryks- og kommunikationsformer og indbyder til ejerskab og deltagelse. At bruge involverende og visuelle metoder, gør det muligt at forske demokratisk og i fællesskab.I dette tilfælde sker det sammen med de unge og pædagogerne, og således tager vi livtag med magtfordelingen imellem deltagerne i forskningen (Crivello, Camfield \& Woodhead, 2008; Einarsdottir, 2006). Denne involvering af deltagerne er en væsentlig del af det at bedrive aktionsforskning og udforske børne- og ungeperspektiverne. At vælge en sådan tilgang, eliminerer på ingen måde magtforholdene i forskning. Nærmere kalder et sådant valg på skærpede refleksioner over forskerposition og konkrete tiltag i processen $^{3}$.

Indsamlingen af fotos, tegninger og digte foregik i projektets fase 1. På tre workshops arbejdede vi med materialet, f.eks. ved at de unge interviewede hinanden om materialerne eller indgik i dialog med forskere og pædagoger. De unge arbejdede også individuelt med skriftlige uddybninger af materialet. Udforskningen af ungeperspektiverne blev afsluttet med et fokusgruppeinterview med 4-6 unge på hver skole. For at forfølge ambitionen om en demokratisk proces med fokus på de unges egne perspektiver, tog interviewene udgangspunkt i de unges materiale. At tage udgangspunkt i de unges materialer og perspektiver er en rød tråd gennem hele projektet. Med det multimodale og eksplorative design dikterer vi ikke, at de unges empiriproduktion skal rette sig mod en konkret definition eller videnskabelig forståelse af trivsel. Designet fastholder åbenhed og kompleksitet, ved at understrege, at det er de unges egne valg, der er afsæt for produktio-

3 For sammenlignelige diskussioner om børne- og ungeperspektiver, magt og forskerposition se f.eks. Gravesen et al., 2019 
nen af empiri; om det er deres indre tilstand, deres forhold til kammerater, lærere, pædagoger og forældre eller fagene i skolen eller noget helt fjerde, der ligger til grund for deres forståelser af trivsel, afgør de selv. Endelig stræber vi efter at imødekomme den epistemologiske præmis om trivsel som komplekst, socialt og foranderligt fænomen ved at dyrke dialogen imellem projektets forskellige deltagere, og således være åbne for gensidige påvirkninger og varierende synsvinkler. Nærmere bestemt dyrkes dialogen fx via en række dialogworkshops, hvor de unges fotos, tegninger, digte og perspektiver drøftes og undersøges i fællesskab samt i fokusgruppeinterviews med de unge.

Undervejs og i efterrationaliseringer har vi haft mange diskussioner af vores tilgang og metode i projektet. Med hinanden (forfatterne til artiklen), pædagoger og unge i projektet, samt kolleger har vi reflekteret over vores ambitioner om at "tage udgangspunkt i de unges perspektiver", og hvordan dette overhovedet er muligt i et projekt, der er iscenesat og organiseret af voksne? For om end, som anført ovenfor, at det var de unge, der valgte, hvad de ville tage billeder af, tegne eller digte om, så var det os, der udtænkte netop den tilgang og valgte de udtryksformer. I diskussionerne, der blandt andet fandt sted i ovennævnte workshops, fokusgruppeinterviews med hhv. unge og pædagoger, var en af tilbagemeldingerne således, at arbejdet med henholdsvis fotos, tegninger og digte på de forskellige workshops, efterhånden for nogle elever havde fremstået en anelse ensformigt, ikke mindst, fordi formen på workshops blev gentaget fra gang til gang; materialerne skulle lægges frem, de unge skulle indgå i dialog, og der var forskellige opsamlinger undervejs. Hvad ville der være sket, hvis vi fra start havde spurgt de unge, hvilke data, de mente vi skulle indsamle i projektet? Og hvordan havde workshops forløbet, hvis ansvaret for aktiviteter og dialog var tildelt dem?

I analysen anvender vi Helle Rabøl Hansens definition af skoletrivsel, som en triade imellem velvære, virke og vellidthed. Omend brugen af en sådan definition umiddelbart kan synes at stride imod vores argumentation om epistemologisk kompleksitet, så betragter vi det omvendt. Hansens definition indeholder mange aspekter ved trivselsbegrebet og tillader et nuanceret blik på unges trivsel i udskolingen. Mere end at lukke sig om en entydig forståelse, vurderer vi at Hansens begreber tager bestik af trivselsfænomenets flertydighed. De tre begreber konnoterer således både indre og personlige aspekter (velvære), faglige og skolerelaterede elementer (virke), samt naturligvis relationelle og anerkendelsesbaserede facetter (vellidthed). Hansen betragter i øvrigt disse som dialektisk forbundne størrelser, hvilket ligeledes bidrager til forståelsen af dynamik og kompleksitet.

\section{Imod en analyse af et mangfoldigt materiale}

Ved gennemgangen af vores empiriske materiale, der tæller omkring 150 fotos, 120 tegninger, 100 digte, feltnoter fra 8 observationsdage, samt interviewudskrifter fra 4 fokusgruppeinterviews, sandede vi hurtigt, at den epistemologiske pointe om trivsel som et komplekst og socialt konstrueret fænomen (Marschall \& Ting- 
strup, 2019; Lind 2019; Ereaut \& Whiting, 2008), mere end blot en teoretisk idé, synes at være et adækvat svar på, hvad trivsel er for noget. For med det alsidige materiale foran os, var det netop mangfoldigheden og livligheden i de unges ytringer og artistiske udtryk, der forekom mest slående. Materialet rummer alt fra fotos af madkasser og drikkedunke, tegninger af havnefronter og badestrande, til digte om angst og venskaber. I fokusgruppeinterviews brugte de unge ofte brede formuleringer, når de skulle give deres bud på, hvad de forstod ved trivselsbegrebet. "At have det godt", "hygge og sjov" eller "vore glad" var gængse svar, og i fokusgruppeinterviewet på skole $\mathrm{C}$ svarede Peter: "Det er faktisk et ret svcert spørgsmål at suare på”.

I den analytiske proces er mangfoldigheden i materialet og bredden i de sproglige svar naturligvis en udfordring, idet netop kompleksiteten og flertydigheden må begribes og styres, så formidlingen af materialet kan fremstå i kategorier, der er læsbare og overskuelige. Vi opererer med fire kategorier; fællesskaber, frikvarter, fag og frihed, som vi uddyber i den følgende analyse. Kategorierne, som i den analytiske proces viste sig at være de bærende, er konstrueret ud fra tværgående læsninger og systematiske bearbejdninger af det indsamlede empiriske materiale og på baggrund af dialoger med de deltagende unge og pædagoger. I udvælgelses- og kategoriseringsprocessen arbejdede vi os helt konkret frem ved at lægge alle materialer frem på borde, der var skubbet sammen, så der var plads til de mange fotos, tegninger og digte. Her foretog vi grupperinger af materialet, som vi sammenholdt med kodninger af vores interview- og observationsmateriale. Vi gennemførte både sådanne analytiske udvælgelser i forskningsrummet (med deltagelse af artiklens forfattere), men også på skolerne, hvor vi på workshops lagde materiale frem og fik de unges bud på, hvordan materialet kan forstås og kategoriseres. De fire kategorier, der fokuseres på i denne artikel, er således resultater af mange-facetterede processer og blikke fra både forskere og unge. Hertil kan det tilføjes, at det naturligvis er indlysende, at vi i denne omfattende proces måtte foretage en række fravalg og/eller rangordninger af tematikker. Et enkelt eksempel på et tema, der var gennemgående i empirien, men som vi ikke valgte at fokusere mere eksklusivt på, er mad og drikkevarer. Mange unge illustrerer situationer, hvor de spiser sammen eller hvor de udtrykker glæde ved spisefrikvarteret. Her var der således tale om hvad man kunne kalde en analysespire (Kousholt, 2018), som efterfølgende ikke fik "sin egen kategori", men i analyseprocessen i stedet kom ind under kategorien fællesskaber som underkategori. Men fremfor at disse pointer og ungeperspektiver blev fravalgt, placerede vi dem i en del tilfælde under en af de fire bærende kategorier i analysen. Således er kategoriseringsarbejdet ikke alene et spørgsmål om at udelade, men ligeså tit et spørgsmål om at samle flere empiriske aspekter under færre betegnelser. 


\section{At trives i skolen. Fallesskaber, frikvarter, fag... og frihed}

\section{Fællesskaber}

Anton: Der skal venner til i skolen. Ellers bliver det kedeligt

Lone: Ja, ellers bliver det sådan lidt "nu skal vi i skole igen... og loere". Det bliver sådan...

Hanne: ... lidt tamt

Ovenstående uddrag fra fokusgruppeinterviewet på skole $\mathrm{C}$ er illustrativt i forhold til at slå fællesskaber an som dominerende empirisk analysekategori. Det er en gennemgående pointe i materialet, at de unge accepterer skolen som en væsentlig del af hverdagslivet - en formel ramme og nødvendighed. Imidlertid er det tydeligt, at denne ramme og skolens fokus på fag og læring, ikke i sig selv betragtes som det, der giver trivsel. Fællesskaber i form af venskaber og relationer til klassekammerater står centralt. Her eksempler fra de unges digte og tegninger:

\section{Jeg elsker min bedsteveninde \\ hun er en virkelig veninde. \\ Vi har været venner i 8 år \\ vores venskab startede her på skolen et efterår.}

\author{
Vi er i skole \\ og snakker med hinanden \\ og laver lektier \\ det er hyggeligt \\ at jeg ser veninderne \\ i hverdagene
}

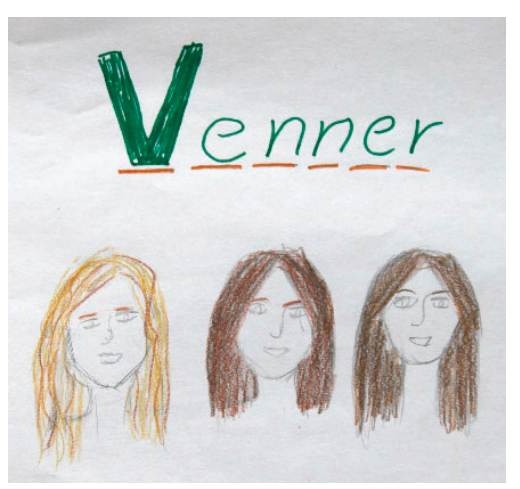

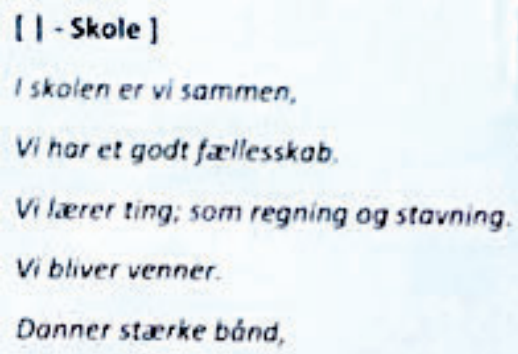

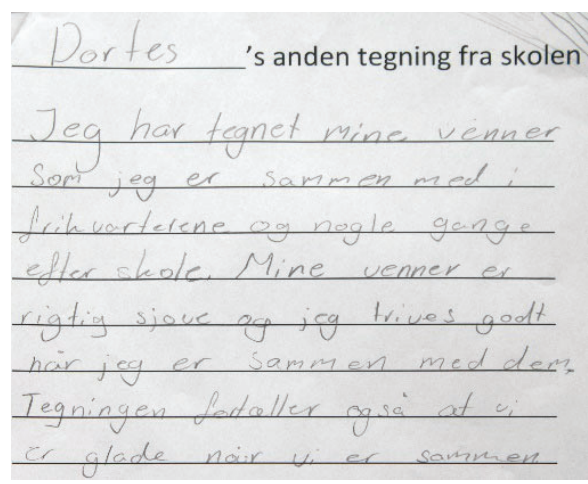

Udover de nære venskaber, fremstår de bredere fællesskaber, både i og udenfor klassen, som centrale for de unges trivsel. Flere udtrykker at det er vigtigt med et klassefællesskab, hvor der er plads til alle. Under en observation på skole D, har 
observatøren en uformel snak med en gruppe elever fra klassen, der er nysgerrige på forskningsprojektet. De fortæller om den seneste trivselsmåling:

\begin{abstract}
Nete, en af pigerne, siger til mig: 'Vi er jo den klasse, der trives bedst. 97\% af os var max i trivsel, da vi svarede på trivselsundersøgelsen og de sidste 3\% svarede "godt"'. Jeg spørger dem til, hvordan det mon kan vare, deres trivsel er så høj. Nete tager igen ordet og siger: 'Jamen, alle kan bare med alle - alle kan snakke sammen [...] De forklarer mig, at der i den anden klasse er lidt mere 'knive på albuerne': 'de er bare lidt hårdere ved hinanden - herinde er vi blidere'
\end{abstract}

Fælles for alle fire klasser er, at der sidder unge, der af den ene eller den anden grund er i en sårbar eller udsat position. Som på skole C, hvor snakken under en observation, falder på en af pigerne fra klassen, der har en diagnose. De unge fortæller, hvordan pigen kom med på deres lejrskoletur og Lone, en af de unge siger: "Jeg var så stolt af Irene. Hun var med hele ugen, selvom hun jo har det lidt svart med andre mennesker".

Empirien rummer dog også tilfælde, hvor klassefællesskabet ikke fungerer optimalt og påvirker trivslen negativt. I ét fokusgruppeinterview efterlyser nogle af de unge, at det store klassefællesskab styrkes, og i et andet udtrykker de unge, at nogle voksne ikke formår at hjælpe, når der er problemer og uvenskab. I observationer er der eksempler på unge, der synes ekskluderet af klassefællesskaberne, f.eks. i en situation, hvor en tre-mandsgruppe efter en konflikt går i opløsning, og den ene af de tre går for sig selv.

På baggrund af en diskussion af forskellige trivselsdefinitioner, foreslår Helle Rabøl Hansen et "skoletrivselsbegreb, der retter sig mod skolen som strukturel og kulturel social betingelse for barnet" (Hansen, 2019, s. 133), hvilket hviler på en forståelse af at skolen både er en (strukturel) institution med regler og rammer, som barnet er pålagt at opholde sig i, men også en (kulturel og social) sammenhæng, hvor barnet er en subjektiv deltager i den måde skoledagen konstrueres. Rabøl formulerer, at skoletrivsel kan forstås som en tilstand, der handler om hhv. 1) elevens oplevelse af psykisk og fysisk velvære i skolen, 2) elevens mulighed for at få adgang til at virke i skolens aktiviteter, samt 3) elevens oplevelse af at være vellidt i skolen. Det synes oplagt at de ovenstående empiriske eksempler knytter an til spørgsmålet om at være vellidt i skolen, men at dette naturligvis også er forbundet med følelsen af psykisk velvære. Karlo fra skole A markerer også med sin tegning om trivsel i skolen, at fællesskabet er vitalt. I en medfølgende tekst forklarer Karlo, at tegningen forestiller en masse

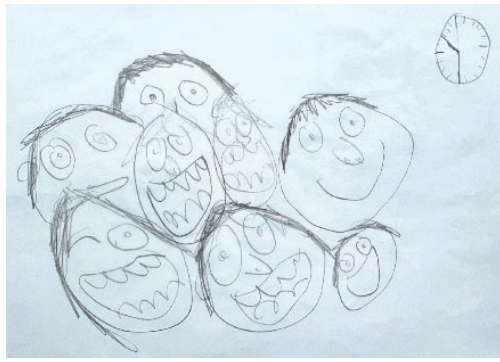
glade børn, og at klokken viser halv 10, hvor der er frikvarter.

\title{
Frikvarter
}

Frikvarter. Denne dag bliver eleverne inde i klasselokalet. To 3-mandsgrupper sidder ved computeren. 4 piger spiser ved samme bord. Inge sidder alene, men da hun 
har spist rykker hun over ved siden af Ask, foran hans computer. Generelt er eleverne sammen foran skcermene denne dag. Ser YouTube, gamer, småsludrer. To af drengene ser informationsfilm om Corona virus på computeren. (Observation, skole C)

Frikvarteret - som de unges eget habitat med deres egne steder, prioriteringer og aktiviteter - er den anden meget gennemgående tematik i materialet. På tegningen nedenfor viser Martha fra skole B, at skoletrivsel for hende er forbundet med veninder, cigaretter, Pepsi max og frikvarter:

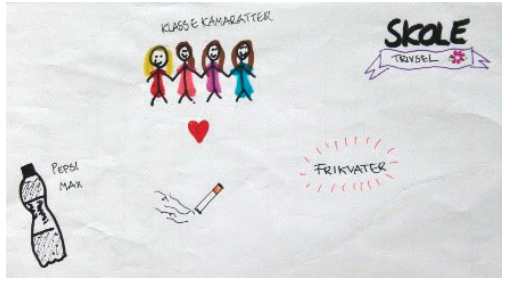

Andre unge har fotograferet skolens toiletter, fordi de her kan hænge ud, uden at nogen (voksne) forstyrrer. Flere fortæller, at toiletter også er et godt sted at holde varmen, når man egentlig skal være udenfor. Dertil kommer fotos og tegninger af skolens udearealer, hvor de unge hænger ud i frikvartererne. Endelig kan frikvarteret, som den ovenstående observation fra skole C illustrerer, foregå i selve klasselokalet. Oftest bedrives frikvarteret med venner og forskellige former for aktivitet, men undertiden også alene som en slags restitution.

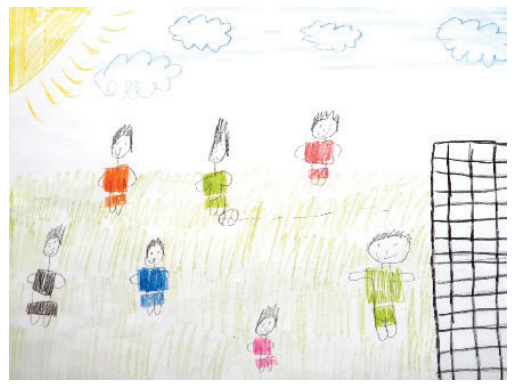

Illustrationer og fortællinger markerer tydeligt de unges behov for at være fri af voksnes indblanding og kontrol. Det at finde sine egne rum og steder er meget gennemgående, men langt fra altid handler det om at gøre noget, som ikke er tilladt, som f.eks. rygning eller ophold indenfor. Oftest er det et spørgsmål om at finde rum til leg, aktiviteter og samvær, som ikke er dikteret af voksne - at gøre noget fordi man har lyst, og fordi det er sjovt. De følgende to eksempler fra illustrerer denne pointe. På sin tegning har Bundu fra skole $\mathrm{C}$ tegnet elever, der spiller fodbold, mens Jytte fra skole D har tegnet spillet "Balle".
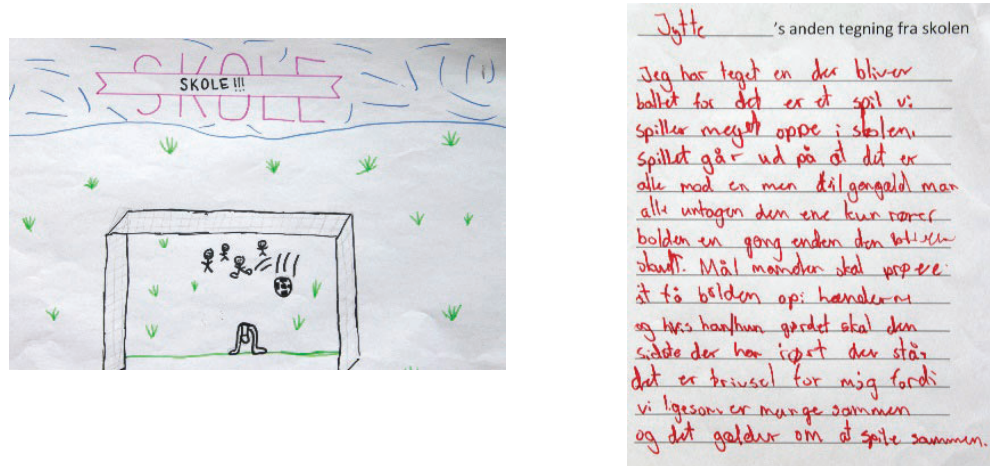

At være fysisk aktiv beskriver Hansen også som et element i elevens velvære i skolen (Hansen, 2019), og i vores materiale viser dette sig som et gennemgående 
tema. Både i de unges egne materialer og i udsagn i interviews og i uformelle samtaler undervejs i observationer, udtrykker mange af de unge glæde ved aktiviteter, der markerer en forskel i forhold til stillesiddende læring på skolestolen. Dette er dog ikke altid tilfældet. Mange markerer således også, at frikvarteret kan bruges med telefonen, eller til at spille computerspil med hinanden. Særligt spillet Among Us er populært
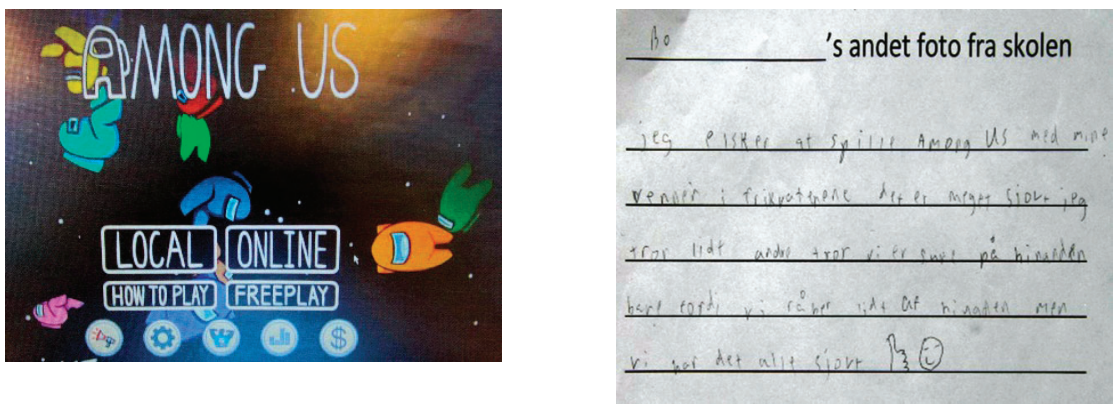

Om end frikvarteret af de fleste beskrives som et rum for de unges egne aktiviteter, så kan det undertiden også være rart, at de voksne er til stede i frikvarteret. Caroline fra skole B har taget et billede af kantinen og i den medfølgende tekst beskriver hun, at det er hyggeligt at sidde sammen og spise brunch, piger og drenge - og lærere, der kan tage kontrol, så skænderier ikke "går over gevind".

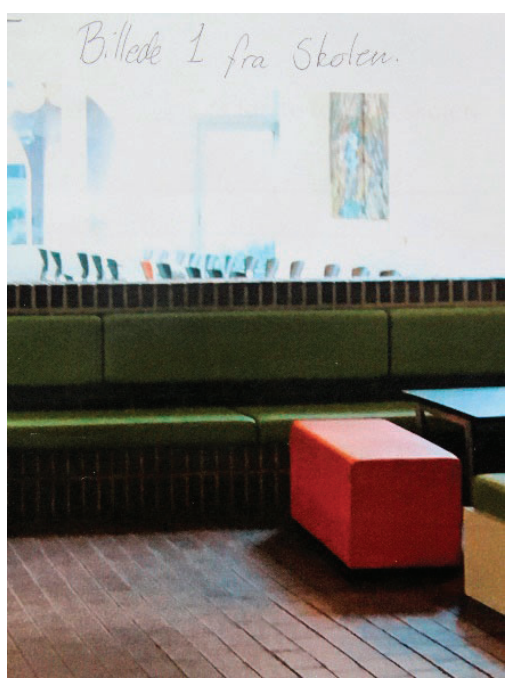

På en anden af skolerne, skole C, er pædagogen Karl ofte tilstede i frikvarteret, hvor han går med på de aktiviteter, de unge selv igangsætter:

Frikvarter. Karl bliver i klassen. Går lidt rundt. Nogle af drengene hoenger på hans ryg, mens han går rundt. De spørger ham til noeste time. Karl: 'Ved I hvad... jeg finder lige computeren frem, så finder vi ud af det hele'. [...] Karl har nu sat sig ned. Fire andre drenge folger ham. En af pigerne har taget spritten og hoelder den $i$ Karls hoender. De griner og smiler til hinanden. Karl snakker lidt computerspil med en af drengene. (Observation, skole C)

Generelt vidner de unges beskrivelser af frikvarteret om et komplekst rum, der både er forbundet med trivsel, pga. muligheden for selvbestemmelse og autonomi, men også skrøbelighed, utryghed og mulige konflikter. Derfor efterspørger de unge undertiden også en vis grad af uformel voksentilstedeværelse, der kan skabe overblik eller en form for tryghed. Skiftet fra elevposition i strukturerede, lærerinitierede fag til ungepositon i frikvarteret, markerer således for mange en kompleks bevægelse. 


\section{Fag}

De to foregående kategorier - fællesskaber og frikvarter - er som nævnt de mest gennemgående tematikker i materialet, mens kategorien fag, som vi fokuserer på i denne del, fremstår mere perifer. Som tidligere nævnt definerer Hansen skoletrivsel som en tilstand bestående af tre forhold, og det andet forhold - "elevens mulighed for at få adgang til at virke i skolens aktiviteter", er centralt i denne del af analysen; når de unge markerer fag, de godt kan lide, lærere, de er glade for eller aktiviteter, de synes er sjove, så er det netop situationer, hvor de med andre ord får adgang til at virke og gøre sig gældende - og hvor dét, de er en del af, synes meningsfuldt for dem (Hansen, 2019, 132).

Nogle unge markerer skolens klassiske og obligatoriske fag som matematik, engelsk, dansk eller historie som yndlingsfag. Nedenfor har Amalie og Travis fra skole B tegnet deres yndlingsfag, hhv. dansk og matematik. Amalie skriver i en medfølgende tekst, at i dansk "sker der altid noget nyt" og at faget er vigtigt. Travis skriver, at han valgte at tegne matematiske formler, fordi "du bruger matematik til at finde ud af hvornår du har fri, du bruger det når du skal beslutte, hvor meget pålceg der skal på din rugbrød, eller når du regner ud hvor meget strøm, der er på din mobil".
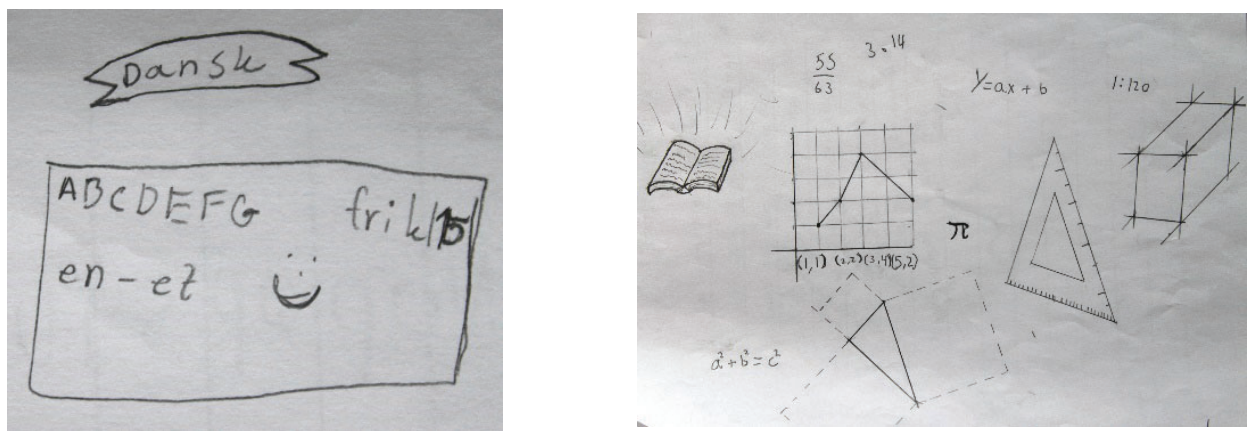

Hvor mange udtrykker, at de kan lide indholdet i specifikke fag, så skriver Gretha fra skole $\mathrm{C}$, at hun har tegnet en hånd, fordi hun "godt kan lide når timerne er stille og rolige, og folk roekker hånden op". At kunne virke i skolen kan således relatere til mange facetter af undervisningen, både dens indhold, organisering og stemningen undervejs.

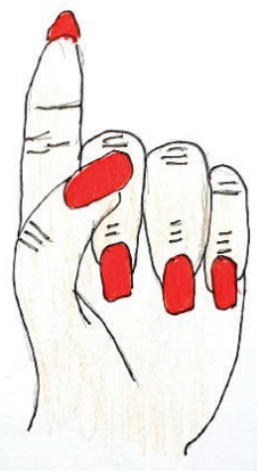

I forhold til stemning og organisering, giver mange unge udtryk for, at de trives godt med gruppearbejde. I fokusgruppeinterviewet på skole $\mathrm{C}$ forklarer Peter, at det er sjovere at arbejde i grupper, selvom man ikke får "lavet ligeså meget, som hvis man sidder alene". Flere er enige, og sådanne ytringer understreger, at om end de unge her udtaler sig om skolens formelle aktiviteter og fag, så oplever de også her fællesskaber og det at kunne arbejde sammen, som centralt for deres trivsel. På den måde veksler tiden i grupperne imellem det faglige arbejde og alt det andet, de har sammen. 


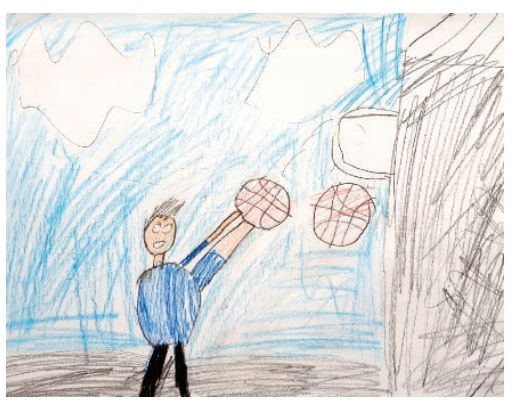

I langt de fleste tilfælde, hvor de unge udtrykker sig positivt om skolens fag, så er det i relation til fag, der har et fysisk, praktisk eller kreativt indhold. F.eks. beskriver Sunday fra skole C i forbindelse med tegningen nedenfor, at han synes det er rigtig sjovt at spille basket i idrætstimerne, og at han godt kunne tænke sig at blive professionel basketball spiller:

Mange unge har tegnet lignende motiver, og flere har taget billeder af hallen eller af deres skoleskema og zoomet ind på idrætstimerne. Et eksempel er Luka fra skole D, der fortæller at han kan lide idræt, fordi man dyrker motion og "ikke skal sidde stille og arbejde med bøgerne"
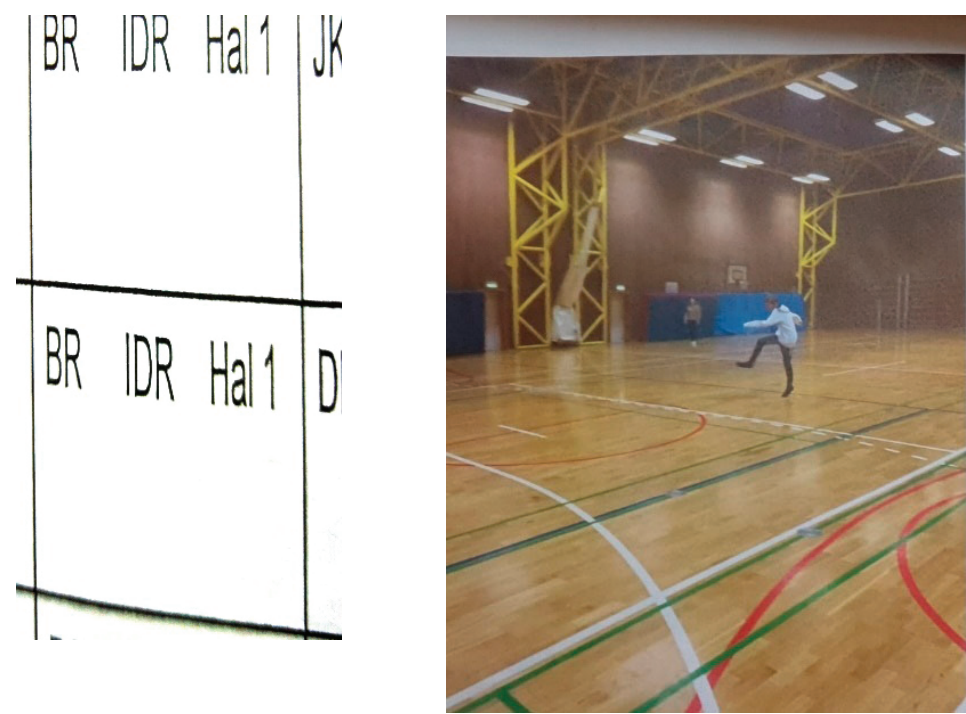

Mange fortæller, at de ikke synes de har idrætstimer nok, og at dage uden fag med fysisk aktivitet er svære at komme igennem:

Ina: Torsdag, det er en lortedag!

Interviewer: Hvorfor?

Nete: Fordi vi har ikke motion og...

Rie: Og vi har dobbelttimer hele dagen!

DanieI: Det er sådan nogle kedelige timer, hvor man ikke laver noget

Nete: Historie, samfundsfag og ... Vi har ikke motion eller noget

Ina: Man sidder meget på sin stol

(Fokusgruppeinterview, skole D)

Udover idræt og andre bevægelsesfag, er også de praktiske og kreative fag populære. Nedenfor har Heidi fra skole C taget et billede i sløjd, som er et valgfag. Her er hun i gang med at dreje en svamp i træ, og hun fremhæver i den medfølgende 
tekst, at faget er sjovt, fordi det er frit, og man kan bestemme selv. Gertrud fra skole D har skrevet et digt om sit valgfag Art and Performance.
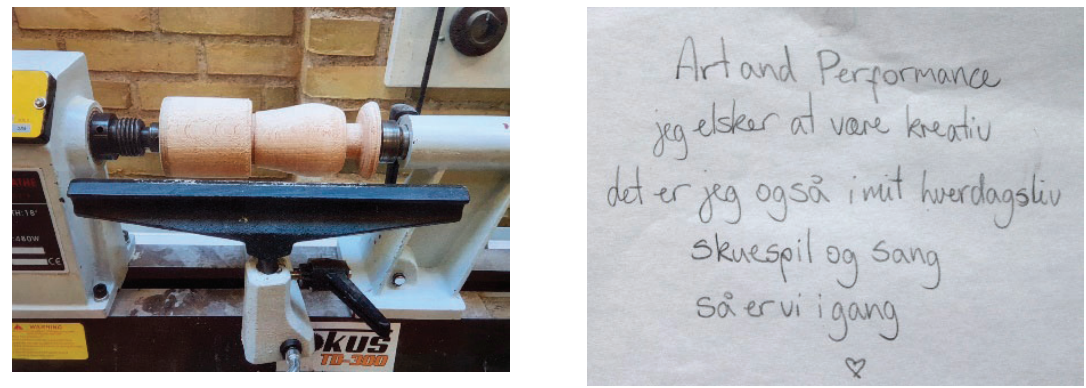

At de mere alternative fag åbner mulighed for at dyrke ens egne interesser, er væsentligt for mange. Som i denne observation, hvor Oskar, der normalt er stille i de almindelige timer, pludselig agerer i et computerrum i valgfaget E-sport, hvor han hjælper sine klassekammerater:

Oskars computer er crashet, så han skal lave et nyt spil for at de kan logge på. "Hvordan gør du det der?" spørger Jan, da Oskar skriver hurtigt på tastaturet. "Det loerer du hurtigt!", svarer Oskar. Oskar er blevet den, der hoster spillet. Det er nu lykkes for alle at komme ind $i$ spillet. De giver hinanden fif og råd $i$ forhold til hvilke kommandoer og knapper de kan trykke på. (skole B)

Udover fagene på skolernes matrikler, er der mange, der udtrykker stor begejstring for ture ud af huset og lejrture. Nedenfor er to eksempler. Først har Gretha fra skole C tegnet sine venner og skrevet Bornholm efterfulgt af en sol, fordi hun "rigtig godt kan lide når de er på lejrtur, og de bliver rystet sammen". Amalie fra skole B har medbragt et billede fra en kanotur, som klassen var på i starten af skoleåret. Hun beskriver at der "var mange gode oplevelser på turen", og at det var en god måde at være sammen på.
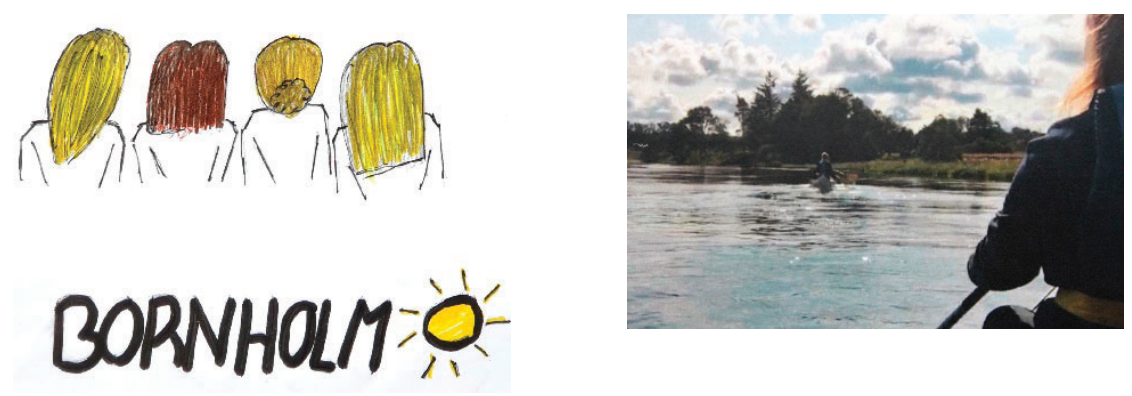

Et sidste aspekt vi vil fremhæve i denne del af analysen er de unges relationer til de voksne, særligt naturligvis lærere, men også i nogle tilfælde pædagoger, der arbejder i udskolingen. I mange uformelle samtaler og i interviews fremhæver de unge betydningen af, hvad de kalder "gode lærere". Her mener de lærere, der er sjove, lærere der ikke skælder ud, og lærere, der tager dem alvorligt og er gode at 
snakke med. Nedenfor har Jytte fra skole D tegnet sin klasselærer, der står og underviser i dansk. Ifølge Jytte er han god, fordi "han holder klassen sammen", og gør, at de trives godt i dansktimerne.

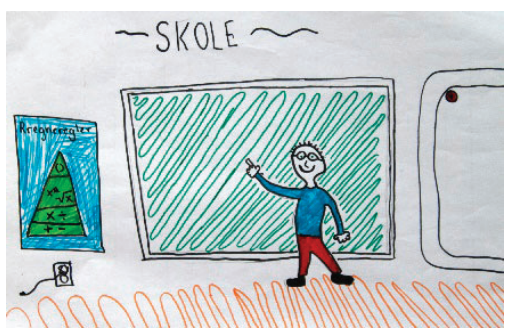

Samtlige de forhold vi har fremhævet i denne del af analysen under overskriften fag, er forhold, de unge har udtrykt sig om som meningsfulde i relation til skolens formelle aktiviteter. Hansen betoner i sin diskussion af skoletrivsel, at hvis elever ikke forstår meningen med undervisningen eller skolens kulturelle rammer, så kan det på sigt føre til marginalisering og eksklusion (Hansen, 2019, 132). Hansen knytter i samme forbindelse an til begrebet fremmedgjorthed, som en slags modpol til der hvor elever oplever skolen og dens aktiviteter som meningsfulde. I næste og sidste del af analysen vil vi præsentere en række eksempler på unge, der udtrykker sig i opposition til skolen, fordi de grundlæggende bare ønsker at være eller blive fri fra den. Udsagn og udtryk, der måske er eksempler på den fremmedgjorthed, Hansen diskuterer.

\section{Frihed}

Som en negation på spørgsmålet om, hvad der får dem til at trives i skolen, svarer, tegner, fotograferer og digter mange af de unge om at komme væk fra skolen, få fri om eftermiddagen og nå frem til weekenden. Mange unge illustrerer modviljen i forhold til skolen ved at tegne eller fotografere ure. Her indikerer de klokkeslæt, der betyder, at skoledagen er ovre, eller at de har frikvarter. Et eksempel er Martin fra skole D, der har tegnet et ur, der, ved et kvikt kig, viser klokken 3. Dette er dog ikke helt præcist nok, for når man læser Martins forklaring i den vedhæftede tekst, skriver han: "På uret kan man se, at klokken er 1 sekund $i$, siden jeg godt kan lide at have fri og det er også den bedste og eneste gode del af dagen. Grunden til at det er 1 sekund $i$ er, at vi jo skulle skrive om skolen, og det er det tcetteste på fri, jeg kan tegne".

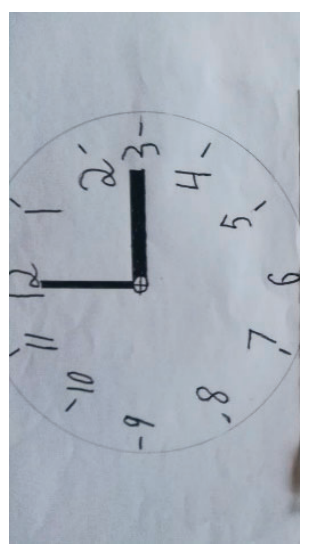

Også Parna fra skole C nærer negative følelser i forhold til skolen. Som det fremgår nedenfor på hendes tegning, har hun centralt placeret en forbudstavle fyldt med bogstaver. Udenfor skolebygningen er en trist elev på vej til skole, og indenfor sidder en elev og tænker på at få fri. Der er et stort bedrøvet ansigt med en tåre på kinden, men også andre smilende ansigter. I den medfølgende tekst skriver Parna om skolen og veninden Berta: "Jeg hader skole. Føler mig alene og utilpas $i$ omgivelserne. Skolen er lang og hård, men Berta gør så jeg kan gennemfore dagen. Hvis Berta ikke var her ville jeg ikke kunne komme op på skolen". 


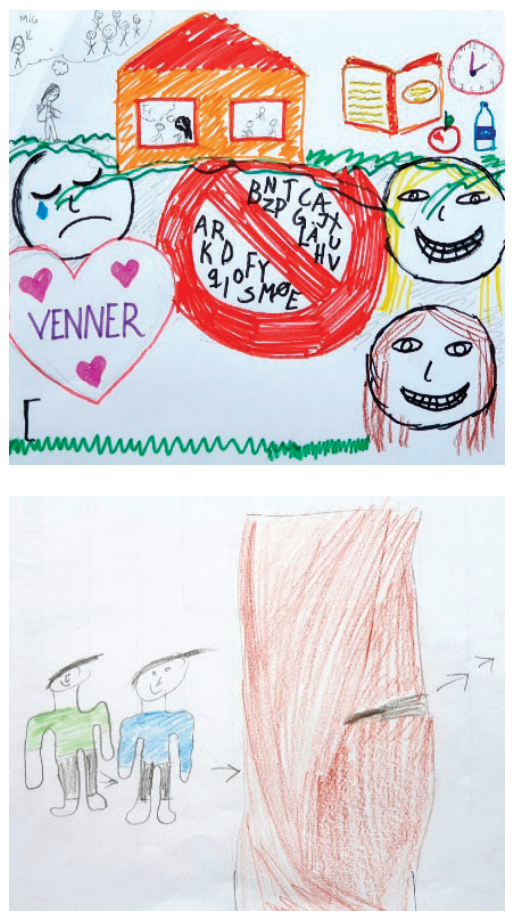

vis også er rigtigt. Men går man bagom denne naturlige selvfølgelighed, så kan man jo spørge, hvad sådanne ytringer egentlig er udtryk for? At unge er dovne og hellere vil slappe af og bestemme selv? Eller at skolen, som den praktiseres mange steder, konstruerer stemninger og organiseringer, der ikke befordrer trivsel blandt alle unge?

\section{Afrunding}

Analysen understreger, at trivsel er et komplekst og foranderligt fænomen, der til stadighed (re)konstrueres i mødet mellem de unge, deres lærere, pædagoger og skolen som organisation og formel ramme. De forskellige fag, aktiviteter, graden af selv- og medbestemmelse, muligheden for fællesskaber og samarbejde præger skoletrivslen på forskellig vis. Trivslen er til stadig forhandling. I analysen anlyserer vi fire empiriske kategorier: fællesskaber, frikvarter, fag og frihed, der sammenholdt med Hansens tre begreber velvære, virke og vellidthed, understreger de komplekse, foranderlige og ikke mindst relationelle aspekter ved de unges trivsel i udskolingen. Hansen understreger, at velvære, virke og vellidthed er dialektisk forbundne størrelser: "Uden vellidthed bliver det vanskeligere at virke, og uden adgang til virke, bliver velvcere begrcenset og udfordret" (Hansen, 2019, s. 133). Om end alle tre begreber træder frem i vores empiri, så synes pointen omkring vellidthed at stå som dominerende markør. Med andre ord, uanset om det handler om venskaber, klassefællesskaber, yndlingsfag, gruppearbejde, "gode" lærere og pædagoger, eller misstemninger i forhold til skolen, så står spørgsmålet om det 
relationelle helt centralt. En pointe, der i øvrigt går igen i andre undersøgelser omkring trivsel i skole og ungdomsuddannelse (Knoop, Holstein, Viskum \& Lindskov, 2017; Powell et al, 2018). Jens Christian Nielsen skriver i forskningsoversigten "Elevtrivsel $i$ gymnasieskolen" om de forskningsprojekter, der omhandler unges egne trivselsperspektiver:

Selvom det kan voere vanskeligt for elever at svare entydigt på, hvad trivsel er og betyder for dem, så peger de iscer på relationelle forhold som en nøglefaktor for deres trivsel $i$ skolen. Både relationer til andre elever og til loerere fremstår som betydningsfulde for elevers sociale og faglige trivsel i skolen $(2020$, s. 9)

Spørgsmålet er hvad denne viden kan bruges til? Hvordan kan artiklens fund gribes og operationaliseres i konstruktioner af pædagogers rolle? Hvilke tiltag og aktiviteter kan der fremadrettet arbejdes med i udskolingen med pædagogen som trivselsaktør? Og hvordan kan der skabes balance imellem, hvad man kunne kalde en klassisk fritidspædagogisk fagidentitet (Ankerstjerne (red.), 2010; Hviid \& Højholdt, 2012; Ringskou, Bach \& Vengsgaard, 2020) og en mere moderne pædagog-variant, der tager bestik af de eksistentielle og relationelle udfordringer og faglige krav, unge møder i udskolingen, nu i 2020'erne? Artiklens ærinde har ikke været at komme frem til svar på disse spørgsmål, men at invitere til videre refleksion og diskussion herom med afsæt i de unges stemmer.

\section{Litteratur}

Ankerstjerne, T. (2010). Fritidspædagogik - før, nu og lige om lidt! I T. Ankerstjerne, SFO- og fritidspcedagogik - før, nu og i fremtiden (s. 49-74). København: Dafolo.

Ankerstjerne, T., \& Stæhr, M. (2018). Grundlag for pcedagogfaglighed i fritid og skole. København: Undervisningsministeriet.

Brown, R., Falkenberg, H., \& Rasmussen, M. S. (2020). Ungdom i udskolingen. København: Forlaget Unge Pædagoger.

Brydon-Miller, M. e. (2011). Jazz and the Banyan Tree. I N. K. Denzin, Y. S. Lincoln, \& (red.), The SAGE Handbook of Qualitative Research. (s. 387-400). SAGE.

Clark, A., \& Moss, P. (2001). Listening to Young Children: The Mosaic Approach. London: National CHildren's Bureau.

Clark, A., \& Stratham, J. (2005). Listening to young Children: Experts in their own lives. Adoption and Fostering, 45-56. doi: 10.1177/030857590502900106

Crivello, G., Camfield, L., \& Woodhead, M. (16.. September 2008). How Can Children Tell Us About Their Wellbeing? Soc. Indic Res(90), 51-72. doi:DOI 10.1007/s11205-008-9312-x

Duus, G. (2015). Indledning. I G. Duus, M. Husted, K. Kildedal, E. Laursen, \& D. Tofteng, Aktionsforskning. En grundbog. (s. 13-19). København: Samfundslitteratur.

Einarsdottir, J. (August 2006). Playschool in pictures: children's photographs as a research method. Early Child Development and Care, 523- 541. doi: https://doi.org/10.1080/03004430500131320

Epinion. (2017). Kortloegning af skoledagens loengde. København: Undervisningsministriet. Hentet fra https://backend.folkeskolen.dk/ /4/1/epinion---kortlaegning-af-skoledagens-laengde-2017. pdf 
Ereaut, G., \& Whiting, R. (2008). What do we mean by 'well-being'? And why might it matter? Research Report DCSF-RW073, Department for children, schools and families, 1-21. doi:https:// dera.ioe.ac.uk//8572/

EVA. (2016). Kendetegn ved kvalitet $i$ klub og fritidstilbud. København: EVA.

Gravesen, D. T., \& Ringskou, L. (2017). On the move from pedagogy to timeagogy? IJREE. International Journal for Research on Extended Education, 164-177.

Gravesen, D. T., Mikkelsen, S. H., \& Frostholm, P. H. (2019). Imellem inddragelse og adultocentrisme: Metodologiske refleksioner over udfordringer og paradokser i kvalitativ børne- og ungeforskning. Norsk sosiologisk Tidsskrift, 30-48.

Görlich, A., Pless, M., Katznelson, N., \& Graversen, L. (2019). Ny udsathed $i$ ungdomslivet. København: Hans Reitzel.

Hansen, H. R. (2019). Jeg hader, hader, hader skole - mistrivsel i skolen set fra pædagogiske perspektiver. I T. Ankerstjerne, Pcedagogik mellem skole og fritid (s. 125-139). Dafolo: København.

Hviid, P., \& Højholdt (red.), C. (2012). Fritidspæedaoik og børneliv. København: Hans Reitzel.

Højholdt, A., Arndal, L., Blaabjerg, B., \& Højmark, U. (2015). På kanten af skolen. Skoletilknytning og forebyggelse $i$ et ungdomsperspektiv . København: Det Kriminalpræventive råd.

James, A. (2007). Giving Voice to Children's Voices: Practices and Problems, Pittfalls and Potentials. American Anthropologist, 261-272. doi:10.1525/aa.2007.109.2.261

Knoop, H. H., Holstein, B. E., Viskum, H., \& Lindskov, J. M. (2017). Elevernes foellesskab og trivsel $i$ skolen. København: DCUM.

Kofoed-Heller, K., Hansen, M. B., \& Dupont, S. (2017). Pcedagogen i skolen - mødet med andre institutionslogikker. Hentet fra https://ucc.dk/sites/default/files/moedet_med_andre_institutionslogikker.pdf

Kousholt, D. (2018). Praksisteoretisk analyse - børnefamiliers hverdagsliv som eksempel. I L. Bøttcher, D. Kousholt, \& D. Winther-Lindqvist, Kvalitative analyseprocesser (s. 263-287). København: Samfundslitteratur.

Lind, U. (2019). Trivsel $i$ daginstitutionens hverdagsliv - et spørgsmål om det kropslige, kollektive og konfliktuelle. København: Roskilde Universitet. Hentet fra https://rucforsk.ruc.dk/ws/ files/65785257/Unni_Lind_PhD_afhandling.pdf

Marschall, A., \& Thingstrup, S. H. (2019). Indledning: trivsel mellem politik, pædagogik og praksis. I A. Marschall, \& S. Thingstrup, Trivsel i dagsinstitutionen - mellem politik, pcedagogik og praksis (s. 17-35). Akademisk forlag: 2019.

Nielsen, J. C. (2020). Elevtrivsel i gymnasieskolen. København: DPU.

Ottesen, M. H., Andreasen, A. G., Dahl, K. M., Hestbæk, A.-D., Lausten, M., \& Rayce, S. B. (2018). Børn og unge i Danmark - velfoerd og trivsel 2018. København: VIVE.

Pless, M., \& Sørensen (red.), N. U. (2018). Ungeperspektiver. Toekninger og tilgange i ungdomsforskningen. Aalborg: Aalborg Universitetsforlag.

Pless, M., Katnelson, N., Hjort-Madsen, P., \& Nielsen, A. W. (2015). Unges motivation i udskolingen. Aalborg: Aalborg Universitetsforlag.

Powell, M. A., Graham, A., Fitzgerald, R., Thomas, N., \& White, N. E. (12.. Maj 2018). Wellbeing in schools: what do students tell us? The Australian Educational Researcher, 515-531.

Rasmussen, M. S., (April 2017). Når skole og skateboarding bliver til et. Social Kritik, 85-98.

Ringskou, L., Vengsgaard, C., \& Bach, C. (Oktober 2020). Klubpædagogen mellem demokrati, frihed og markedsgørelse? Tre nøglefortællinger om klubpædagogisk professionsidentitet. FPPU(2), 65-81. Hentet fra https://tidsskrift.dk/FPPU/issue/view/8862

Simmons, C., Graham, A., \& Thomas, N. (2015). Imagining an ideal school for wellbeing: locating student voice. Journal of Educational Change, 129-144.

Thingstrup, S. H. (2019). Trivselsarbejde i daginstitutioner som sammenhængs- og afgrænsningsarbejde. I A. Marschall, \& S. H. Thingstrup, Trivsel i daginstitutionen - mellem politik, pcedagogik og praksis (s. 95-115). København: Akademisk. 